\title{
The Socialist Countries, North Africa and the Middle East in the Cold War: The Educational Connection
}

\author{
Constantin Katsakioris \\ Institute of World History, Charles University in Prague, Czech Republic \\ Konstantinos.Katsakioris@ff.cuni.cz
}

This article revisits the Eastern Bloc's educational assistance provided to North Africa and the Middle East during the Cold War. It highlights the political and economic premises, interests and policies at play, and investigates the role of the Council for Mutual Economic Assistance. It examines the creation of schools in North Africa and the Middle East and the training of students in the socialist countries. The article argues for the centrality of education in the international policy of the Eastern Bloc, further demonstrating its importance in the political economy of the relations with the countries of North Africa and the Middle East.

As early as 1957 Mohand Ali Yahia and Boubaker Adjali, both activists of the Algerian Liberation Front (Front de Libération Nationale; FLN) during the French-Algerian War (1954-62), found refuge in East Germany. By that time, East Germany, along with the other socialist countries, ${ }^{1}$ was actively supporting the Algerian cause, hosting nearly 200 Algerian refugees. ${ }^{2}$ Some of those refugees were admitted to universities, technical institutes or political schools. Ali Yahia studied film direction at the East Berlin Film School, from which he graduated in 1961. His comrade, Adjali, was transferred to Czechoslovakia after receiving medical treatment, where he enrolled in the Prague Film and TV School (FAMU). After his training, Adjali pursued his trajectory as an activist documentarian, making films about the liberation movements fighting against Portuguese colonialism. At FAMU he had been joined by another Algerian militant, Mohammed Lakhdar-Hamina. A brilliant student of socialist aesthetics, Lakhdar-Hamina would receive the Best First Work Award at the Cannes Film Festival in 1966 for his work The Winds of the Aures, a classic cinematic portrayal of the Algerian Revolution. He is widely recognised today as one of the founding fathers of Algerian cinema. ${ }^{3}$

Around the same time, the Soviet Union was also offering scholarships and hosting increasing numbers of Algerian students on the recommendation of the FLN and the General Union of Algerian Muslim Students (Union Générale des Étudiants Musulmans Algériens; UGEMA). ${ }^{4}$ Among the first of these students was Mohamed Lakhdar Benhassine, who studied Economics at Moscow State University between 1956 and 1962, and pursued postgraduate studies at the Higher School of

\footnotetext{
1 For practical reasons, I use the term 'socialist countries' as a synonym for the Eastern Bloc.

2 See Patrice Poutrus, 'An den Grenzen des proletarischen Internationalismus. Algerische Flüchtlinge in der DDR', Zeitschrift für Geschichtswissenschaft, 2, (2007), 162-78.

3 Olivier Hadouchi, 'Mohammed Lakhdar-Hamina and Boubaker Adjali: The Careers of two Algerian Filmmakers who attended FAMU', in Tereza Stejskalová, ed., Filmmakers of the World, Unite! Forgotten Internationalism, Czechoslovak Film and the Third World (Prague: Tranzit Edice, 2017), 123-36. FAMU is the acronym for Filmova a televizni fakulta Akademie muzickych umèni. The school was part of the Academy of Performing Arts.

4 On the history of UGEMA, see Henry Clement Moore, ed., Combat et solidarité estudiantins: L'UGEMA (1955-1962). Témoignages (Alger: Casbah Éditions, 2010); Ahmed Mahi, De l'UGEMA à l'UNEA. Témoignage sur le mouvement étudiant (1959-1965) (Algiers: INAS Éditions, 2014).

(c) The Author(s), 2021. Published by Cambridge University Press. This is an Open Access article, distributed under the terms of the Creative Commons Attribution licence (http://creativecommons.org/licenses/by/4.0/), which permits unrestricted re-use, distribution, and reproduction in any medium, provided the original work is properly cited.
} 
Economics (Hochschule für Ökonomie) in East Berlin, where he was awarded his $\mathrm{PhD}$ in December 1967. Back in Algeria, Benhassine became an activist of the outlawed Socialist Vanguard Party (Parti de l'Avant-Garde Socialiste; PAGS). At the same time, he had emerged as a respected Marxist economist and academic, remembered after his passing in 2014 as 'the man who saved the honour of the Algerian University'. ${ }^{6}$ Another major figure of this revolutionary cohort was Mustapha Negadi, a UGEMA leader, who was granted his scholarship through the Prague-based International Union of Students (IUS) and attended the prestigious Sechenov Medical Institute in Moscow. Negadi advocated the Algerian cause in Moscow, Tokyo and Beijing, and treated wounded Algerian fighters during the war. After independence he served at hospitals, became a prominent Algerian psychiatrist and, more recently, was the author of An Algerian-Soviet Novel. ${ }^{7}$

Scholarship on the relations of the socialist countries with the Middle East and North Africa has concentrated on issues of war and peace as well as military and political cooperation at the expense of aid and exchange in such fields as education, science and culture. Despite the renewed interest in the international cultural and education policies of the socialist countries, most historians have neglected this region. They have focused instead, with plenty of good reasons, on sub-Saharan Africa. More specifically, such scholars have detailed how African studies developed after the Thaw, revisited the debates and often iconoclastic approaches among Africanists and political economists ${ }^{8}$ and studied race relations in the Eastern Bloc in some depth. ${ }^{9}$ The literature on educational assistance to sub-Saharan Africa has witnessed remarkable growth. East German educational assistance to East Africa alone, for example, has been thoroughly studied, and such scholarship stands out for its importance. On the one hand, scholars have examined the training and experiences of students from Zanzibar and Tanzania, Ethiopia, Mozambique and such institutions as the Stassfurt School of Friendship. On the other hand, they have investigated the contributions of East German professors and experts in the establishment of a number of schools and the general development of education in East African countries. It is safe to argue along with these scholars that educational assistance was instrumental in training a socialist-minded intelligentsia, strengthening bilateral ties and supporting the development of friendly regimes along socialist lines until the late $1980 \mathrm{~s}^{10}$

\footnotetext{
5 Mohamed Lakhdar Benhassine, 'Die Industrialisierung Algeriens und der Akkumulationsprozess als Mittel ihrer Verwirklichung', PhD Thesis, Hochschule für Ökonomie in Berlin, 1967.

6 Bachir Dahak, 'Mohamed-Lakhdar Benhassine ou l'honneur sauvé de l'université algérienne', Alger républicain, 18 July 2017, http://www.alger-republicain.com/Mohamed-Lakhdar-Benhassine-ou-1.html (last visited 30 June 2021).

7 Mustapha Negadi, Un roman algéro-soviétique. Aux origines de l'UGEMA (Alger: Dar El Adib, 2014). See also Negadi's interview with Moore in, Combat, 459-70.

8 Apollon Davidson, ed., Stanovlenie otechestvennoi afrikanistiki 1920-e - nachalo 1960-kh (Moscow: Nauka, 2003); Steffi Marung, 'Entangling Agrarian Modernities: The “Agrarian Question" through the Eyes of Soviet Africanists', in James Mark, Artemy Kalinovsky and Steffi Marung, eds., Alternative Globalizations: Eastern Europe and the Postcolonial World (Bloomington: Indiana University Press, 2020), 145-64. There are also many references to Africa in Malgorzata Mazurek, 'Polish Economists in Nehru's India: Making Social Science for the Third World in an Era of de-Stalinization', Slavic Review, 77, 3 (2018), 588-610.

9 Sergey Mazov, 'Afrikanskie studenty v Moskve v god Afriki (po arkhivnym materialam)', Vostok, 3, (1999), 89-103; Julie Hessler, 'Death of an African Student in Moscow: Race, Politics, and the Cold War', Cahiers du Monde russe, 47, 1-2, (2006), 33-64; Maxim Matusevich, 'Journeys of Hope: African Diaspora and the Soviet Society', African Diaspora, 1, (2008), 53-85; Quinn Slobodian, ed., Comrades of Color: East Germany in the Cold War World (New York: Berghahn, 2015).

10 Tanja Müller, Legacies of Socialist Solidarity: East Germany in Mozambique (Lanham: Lexington Books, 2014); Berthold Unfried, 'Friendship and Education, Coffee and Weapons: Exchanges between Socialist Ethiopia and the German Democratic Republic', Northeast African Studies, 16, 1, (2016), 15-38; Marcia Schenck, 'Small Strangers at the School of Friendship: Memories of Mozambican School Students of the German Democratic Republic', GHI Bulletin Supplement, 15, (2020), 41-59; Eric Burton, 'Navigating Global Socialism: Tanzanian Students in and Beyond East Germany', Cold War History, 19, 1, (2019), 63-83; Eric Burton, 'Engineering Socialism: The Faculty of Engineering at the University of Dar es Salaam (Tanzania) in the 1970s and 1980s', and Alexandra Pepiorka, 'Exploring "Socialist Solidarity” in Higher Education: East German Advisors in Post-Independence Mozambique (1975-1992)', both in Damiano Matasci, Miguel Bandeira Jerónimo and Hugo Gonçalves Dores, eds., Education and Development in Colonial and Postcolonial Africa: Policies, Paradigms, and Entanglements, 1890s-1980s (Basingstoke: Palgrave Macmillan, 2020), 205-33 and 289-318.
} 
In sharp contrast, the Eastern Bloc's educational cooperation with and assistance provided to the Arab or predominantly Arab countries of North Africa and the Middle East has received only scattered attention. Again, a number of path-breaking studies have concentrated on East Germany, both as a host country for Algerian, Egyptian and Iraqi students, and as a provider of assistance abroad. ${ }^{11}$ Moscow's assistance and training of Arab students in the Soviet Union, in particular at the Patrice Lumumba Peoples' Friendship University in Moscow, have been explored in other accounts. ${ }^{12}$ A distinct strand of the scholarship in the French language has put the spotlight on student migration from and the return to former countries of the French empire. ${ }^{13}$ Students of cinema and literature have perhaps conducted the most extensive body of research on these particular issues, retracing the trajectories and analysing the work of the numerous talented men who attended FAMU in Prague and the Gerasimov Institute of Cinematography (VGIK) in Moscow. ${ }^{14}$ These contributions notwithstanding, crucial chapters in this history are still missing, and, as a consequence, the significance of the Eastern Bloc-Middle East educational connection in the historiography has been downplayed.

The present article seeks to redress this imbalance. Pointing to key developments and retrieving missing chapters and links, it will argue for the centrality of education in the international policy of the socialist countries and within the political economy of their relations with North Africa and the Middle East. One after another, as the article will show, the socialist countries carried out concerted efforts to provide training to students, effectively raising education into a major tool in their ambitious policy in this region. Unlike educational aid to Asia and Latin America, which was very heavily concentrated on fellow socialist countries, ${ }^{15}$ and unlike assistance delivered to sub-Saharan Africa which, beyond socialist Ethiopia, Angola, Mozambique and Congo Brazzaville, benefitted numerous countries, often regardless of political or economic orientation, ${ }^{16}$ educational aid to North Africa and the Middle East also came with a distinct regional rationale. This rationale reflected geostrategic and economic interests, and partly accounts for the fact that the region became an arena of intense Eastern Bloc activity and major educational commitments, with notable exceptions such as Saudi Arabia, Turkey or Iran after 1979. In resource poor but strategically located Yemen, the mass training of students eventually became the single most important tool for building up a friendly socialist regime after military aid. ${ }^{17}$ In hydrocarbon rich countries like Algeria or Iraq, educational aid was provided and cooperation unfolded with an eye on economic relations.

11 Damian Mac Con Uladh, 'Guests of the Socialist Nation? Foreign Students and Workers in the GDR', PhD Thesis, University College London, 2005; Amélie Regnauld, 'La RDA en Égypte, 1969-1989: La construction d'une politique étrangère. De la solidarité anti-impérialiste aux avantages réciproques', $\mathrm{PhD}$ Thesis, University of Sorbonne - Paris I, 2016; Julia Sittmann, 'Illusions of Care: Iraqi Students between the Ba'thist State and the Stasi in Socialist East Germany', Cold War History, 18, 2, (2018), 187-202.

12 Elena Savitseva, RUDN i arabskii Vostok (The Russian Peoples' Friendship University and the Arab East) (Moscow: Peoples' Friendship University, 2010); Constantin Katsakioris, 'Soviet Lessons for Arab Modernization: Soviet Educational Aid towards Arab Countries after 1956', Journal of Modern European History, 8, 1, (2010), 85-105.

13 See Grazia Scarfò Ghellab, “Les meilleures années de notre vie”. Des ingénieurs marocains formés en URSS’, and Kamal Mellakh, 'La formation des pharmaciens marocains dans les pays de l'Est. Enjeux et expériences', in Monique de Saint Martin et al. eds., Étudier à l'Est. Trajectoires d'étudiants africains et arabes en URSS et dans les pays d'Europe de l'Est (Paris: Karthala, 2015), 187-201 and 205-14. See also the special issue, 'Former des élites: Mobilités des étudiants d'Afrique au nord du Sahara dans les pays de l'ex-bloc socialiste', edited by Michèle Leclerc-Olive and Marie-Antoinette Hily, in Revue européenne des migrations internationales, 32, 2, (2016).

14 Stejskalová, Filmmakers; Rasha Salti, ed., Saving Bruce Lee: African and Arab Cinema in the Era of Soviet Cultural Diplomacy (Berlin: Haus der Kulturen der Welt, 2018); Gabrielle Chomentowski, 'Filmmakers from Africa and the Middle East at VGIK during the Cold War', Studies in Russian and Soviet Cinema, 13, 2, (2019), 189-98.

15 China and North Korea until the early 1960s; Mongolia, Vietnam, Laos, Afghanistan, Cambodia in the late 1980s; Cuba and Nicaragua in the 1980s.

16 Monique de Saint Martin and Patrice Yengo, eds., 'Élites de retour de l'Est. Quelles contributions des élites "rouges" au façonnement des États post-coloniaux?', special issue in Cahiers d'Études africaines, 226, 2, (2017).

17 For the involvement of Eastern Bloc countries in Yemen, see Fred Halliday, Revolution and Foreign Policy: The Case of South Yemen, 1967-1987 (Cambridge: Cambridge University Press, 1990). 
The economic dimension and, more specifically, the developmental logic of educational cooperation constitute a central thread through this article. This applies not only to the socialist side of the connection. Actually, North African and Middle Eastern countries were the most immediately concerned with issues of economic development and state building, and they were often the first ones to seek foreign educational assistance deemed to be indispensable to meeting their objectives. Their views, motives and concerns are briefly discussed in the first part of this article. ${ }^{18}$ The next section shifts the focus to the Eastern Bloc, arguing that the Council for Mutual Economic Assistance (CMEA, also known as COMECON) considered international education as a means of enhancing both economic and political relations with the developing world and sought to coordinate the educational policies of member states. After an interlude introducing various actors entertaining different aspirations, two additional parts detail the ways in which cooperation unfolded: on the one hand, there were the schools created with Eastern Bloc assistance in North Africa and the Middle East and the purposes they served in terms of national development, and, on the other, there was the training of students in the socialist countries. These developments and their effects account for the centrality of education in the political economy of Eastern Bloc-Middle East relations.

Data on students from Arab countries who studied in the Soviet Union and Eastern Europe and comparisons with the West, which are presented in the last section of this article, illustrate the dimensions that educational cooperation acquired. As a powerhouse of international education, the Soviet Union figures prominently in this chapter of history that opened up in the second half of the 1950s and closed abruptly around 1989-91. Neither the Soviet Union nor the other socialist countries, however, could have shaped this historical chapter without the actors from North Africa and the Middle East, who took centre stage.

\section{The Road to Educational Cooperation: Motivations, Constraints and Agreements}

The Conference on Professional and Technical Education held in Cairo in late 1957, as well as the Survey of the Needs of Arab Countries in Education conducted by UNESCO and Arab officials by the end of the 1950s, acknowledged the progress the countries of the Middle East had made in several fields, but also identified crucial shortcomings and pointed to their implications. One of these shortcomings was the lack of specialists in the fields of applied and natural sciences. This dearth compromised the development both of secondary and post-secondary education, as qualified professors of physics or engineering were largely non-existent, and, by extension, the region's economies were compromised. ${ }^{19}$ Even before economists acquired prominence for arguing that investment in human capital could assure higher returns than investment in fixed capital, the connection between education and economic development and the nodal position of elites trained in fields other than liberal arts and religious studies appeared to be very well established among policy makers and beyond. That this connection was ultimately meant to strengthen the nation to fight wars and resist encroachment lent it even more legitimacy. Investment in education, therefore, along with appropriate educational planning and international cooperation, constituted the necessary means of achieving these goals. ${ }^{20}$ The cost of the required policies, however, remained the most serious constraint.

18 Nathan Citino, Envisioning the Arab Future: Modernization in U.S.-Arab Relations, 1945-1967 (Cambridge: Cambridge University Press, 2017); Cyrus Schayegh, 'The Man in the Middle: Developmentalism and Cold War at AUB's Economic Research Institute in-between the US and the Middle East, 1952-1967', in Nadia El-Cheikh, Lina Choueiri and Bilal Orfali, eds., One Hundred and Fifty (Beirut: American University of Beirut Press, 2016), 105-19.

19 Rapport de la Conférence sur l'enseignement professionnel et technique dans les États arabes du Moyen-Orient (Paris: UNESCO, 1958). The Survey is included in the Annex of the Report on the Educational Needs of the Arab Countries (Paris: UNESCO, 1960).

20 On educational planning in Nasser's Egypt and the attraction of the Eastern Bloc, see Valeska Huber, 'Planning Education and Manpower in the Middle East, 1950s-60s', Journal of Contemporary History, 52, 1 (2007), 95-117. On the commitment to planning more general, see Michel Christian, Sandrine Kott and Ondrej Matejka, eds., Planning in Cold War Europe: Competition, Cooperation, Circulations 1950s-1970s (Berlin: De Gruyter, 2018). 
In view of these objectives and constraints, cooperation with the socialist countries appeared in the eyes of many actors as an extremely interesting avenue. In the aftermath of the Suez Crisis, and in the midst of major Soviet achievements in the conquest of space, the political and intellectual context could not have been more inviting. Exhibitions on 'The University of Moscow', 'The Life of Soviet Students' and 'Foreign Students in the USSR' that the Soviet centres for cultural diplomacy organised in Egypt, Syria and Lebanon in 1957 attracted tens of thousands of visitors. ${ }^{21}$ Most importantly, a panoply of newly-founded institutions provided scholarships and increased the popularity of education and sciences in the Eastern Bloc. They included the Soviet Society of Friendship and Cultural Relations with the Arab Countries and its East German equivalent (Gesellschaft DDR-Arabische Länder), both created in $1958,{ }^{22}$ as well as the Peoples' Friendship University in Moscow and the University of the 17th of November in Prague, founded in 1960 and 1961, respectively, to cater specifically to students from Third World countries. ${ }^{23}$ Leftist and nationalist youth organisations from North Africa and the Middle East established close ties with the IUS in Prague and received substantial support in the form of scholarships. Between 1960 and 1962, the year of Algerian independence, UGEMA saw forty-two of its members being admitted to Lumumba University among a total of 253 students from all countries of North Africa and the Middle East. ${ }^{24}$ Hundreds of individual students seeking a chance to pursue their education, and who were usually fascinated with socialism and Soviet power, applied directly to the school. Some successful applicants, however, like three Egyptians who were granted their scholarships in 1960, were arrested at the airport before boarding their flight to Moscow. They paid the price of Cairo's suspicion towards both leftist students and a school that was believed to provide ideological training. ${ }^{25}$

For the reasons sketched out above, not only leftist students and youth organisations but also the majority of Arab governments appeared to be particularly interested, under certain conditions, in cooperating with the socialist countries. They sought to benefit from Eastern Bloc aid, train specialists in specific fields and, at the same time, assume full control over the mobility of their nationals while keeping an eye on their studies. In 1956 Syria signed a cultural agreement with the Soviet Union that provided an exchange in 'arts, science, higher education' and other fields. ${ }^{26}$ Egypt followed suit and signed agreements for technical and cultural cooperation with Czechoslovakia and the Soviet Union in 1956 and 1957, providing for the training of students, mostly in three-year PhD programmes, at Czechoslovak and Soviet institutions, and for the employment of scientists by Egyptian institutions, like the Suez Oil Institute. ${ }^{27}$ Cooperation was also established with Hungary. During the early sixties, along with training students in regular university programmes, Hungary also 'hosted 300 students from Egypt every year for a ten-month practical training programme. ${ }^{28}$ The Agreement of Technical and Economic Cooperation signed by Cairo and East Berlin in March 1965, four years before Egypt even granted diplomatic recognition to East Germany, led to an increase in the number of Egyptian students studying in East Germany and paved the way for East German educationalists to establish schools in Egypt. $^{29}$

${ }^{21}$ Report of the Union of Soviet Friendship Societies: GARF, f. (fond means collection) 9576, op. (opis' is inventory) 12, d. (delo is file) 1, 1. (list means page) 25-7.

22 For the Soviet Society, see GARF, f. 9576, op. 2, d. 61. The East German one is mentioned in Gareth Winrow, The Foreign Policy of the GDR in Africa (Cambridge: Cambridge University Press, 1990), 50.

23 Constantin Katsakioris, 'The Lumumba University in Moscow: Higher Education for a Soviet-Third World Alliance, 1960-1991', Journal of Global History, 14, 2, (2019), 281-300; Marta Edith Holečková, 'Konfliktní lekce z internacionalismu: Studenti z 'třetiho světa' a jejich konfrontace s českým prostředim (1961-1974)', Soudobé Dějiny, 20, 1-2, (2013), $158-76$.

24 For this data, see Central Municipal Archives of Moscow (TsMAM), f. 3061, op. 1, d. 40, 11. 1-12 and d. 91, 11. 1-7.

25 Mentioned by the Egyptian Deputy Minister of Education, 12 Apr. 1961: State Archive of the Russian Federation (GARF), f. 9606, op. 1, d. 940, 1. 134.

26 Karen Dawisha, 'Soviet Cultural Relations with Iraq, Syria and Egypt 1955-70', Soviet Studies, 27, 3 (1975), 426.

27 Petr Zídek and Karel Sieber, Československo a Blízký vychod v letech 1948-1989 (Prague: Ústav mezinárodních vztahů), 62.

28 Report of the Council for Mutual Economic Assistance (CMEA), Jan. 1964, GARF, f. 9606, op. 2, d. 134, 1. 101.

29 Regnauld, 'La RDA', 325. 
On the opposite side, two socialist countries in which Nasser's Egypt refrained from training students were Romania and Bulgaria. Cairo's stance notwithstanding, Bulgaria kept reaching out to Egypt and the Arab world. After the Egyptian president passed away in 1970, the government decided to rechristen the institute for foreign students at the University of Sofia as the 'Institute Gamal Abdel Nasser'. Reminiscent of the Soviet decision to name the Peoples' Friendship University after Patrice Lumumba a decade earlier, this symbolic gesture illustrated the importance of educational exchange and the relations with the Arab world in Bulgaria's international policy. ${ }^{30}$ At the same time, Cairo's stance did not discourage Damascus from embarking on a large scale educational cooperation effort with Bulgaria after Syria seceded from the United Arab Republic in 1961. Following the Agreement of Cultural Cooperation that the two countries settled in August 1962, Syrians quickly became the biggest group of Third World students in Bulgaria. In the mid-1960s Damascus was training nearly as many students in various Bulgarian institutions of higher and professional-technical education as in the Soviet Union (see Table 1 later in the article). Reflecting Damascus's priorities with regard to economic and social development, more than half of Syrian students in Bulgaria pursued training in technical fields (54 per cent), nearly one third studied medicine while far fewer (5 per cent) were involved in agriculture. ${ }^{31}$

Similar in terms of economic objectives and foreign partnerships was the strategy of Iraq, the country which became by far the biggest exporter of students to the Eastern Bloc during the late 1950s and early 1960s. Baghdad's cooperation with the socialist countries began shortly after Brigadier Abd al-Karim Qasim overthrew the pro-Western monarchy in July 1958, growing spectacularly until his regime was toppled by the Ba'th party in February 1963. Qasim notoriously pulled Iraq out of the Baghdad Pact and sought to build a close partnership with the socialist countries. Likewise, on the domestic front, he implemented reforms that were partly inspired by socialism. His major objective was none other than to nationalise the Western-owned Iraq Petroleum Company and to place the oil industry under the full control of the state-owned Iraqi National Oil Company, which he had set up in 1961. ${ }^{32}$ To reach this goal Qasim's government signed agreements for economic and technical cooperation with Czechoslovakia in December 1958 and the Soviet Union in March 1959 that provided training for students, many of whom were destined to serve the national oil industry. ${ }^{33}$ Beginning in the 1959-60 school term, the Iraqi government granted scholarships to hundreds of students. Czechoslovakia did the same, as did the Soviet Union, which, along with the United States, the United Kingdom and West Germany, had emerged as one of the major host countries for Iraqis studying abroad. Seeking diplomatic recognition and economic agreements, East Germany also stepped in. However, as Baghdad increasingly valued its cooperation with West Germany, East Berlin was forced to act at the unofficial level by offering scholarships mostly to members of the Iraqi Communist Party. ${ }^{34}$ Despite some tensions with the Eastern Bloc countries related to their recruitment and protection of communist students, a strategic objective of the educational cooperation appeared to be reached in June 1972, when Iraq finally nationalised the oil industry.

With such objectives in mind, not only Qasim's Iraq but also Egypt and Syria were ready to cover part of the cost for the training of their nationals, who were at that point holders of state scholarships, in the Eastern Bloc. Their agreements with Czechoslovakia and the Soviet Union stipulated that the sending countries should pay for part or most of the scholarships, with the rest being granted by the government of the host country. In all, the provision of a number of scholarships by the host countries, the absence of tuition fees and the low cost of living compared with the West made the training

${ }^{30}$ On these relations, see Theodora Dragostinova, "The "Natural Ally" of the "Developing World": Bulgarian Culture in India and Mexico', Slavic Review, 77, 3, (2018), 661-84.

31 For data on international students per country of origin studying in Bulgaria, see GARF, f. 9609, op. 2, d. 134, 11. 109-13.

32 Adeed Dawisha, Iraq: A Political History from Independence to Occupation (Princeton: Princeton University Press, 2009), 182.

33 Zídek and Sieber, Československo, 92; Aleksandr Fursenko, ed., Arkhivy Kremlia: Prezidium TsK KPSS, 1959-1964 (The Kremlin Archives: Presidium of the CC of the CPSU, 1959-1964) (Moscow: Rosspen, 2008), 837-42.

34 Sittmann, 'Illusions', 190. 
Table 1. Students from selected Arab countries in the Eastern bloc and Yugoslavia in 1963/64 and 1966/67. ${ }^{35}$

\begin{tabular}{|c|c|c|c|c|c|c|c|c|c|c|c|c|c|c|c|c|c|c|}
\hline & \multicolumn{2}{|c|}{ Bulgaria } & \multicolumn{2}{|c|}{$\mathrm{Cz} / \mathrm{SI}$} & \multicolumn{2}{|c|}{ East Germany } & \multicolumn{2}{|c|}{ Hungary } & \multicolumn{2}{|c|}{ Poland } & \multicolumn{2}{|c|}{ Romania } & \multicolumn{2}{|c|}{ Soviet Union } & \multicolumn{2}{|c|}{ CMEA TOTAL } & \multicolumn{2}{|c|}{ Yugoslavia } \\
\hline & $\begin{array}{c}1963 / \\
64\end{array}$ & $\begin{array}{c}1966 / \\
67\end{array}$ & $\begin{array}{c}1963 / \\
64\end{array}$ & $\begin{array}{c}1966 / \\
67\end{array}$ & $\begin{array}{c}1963 / \\
64\end{array}$ & $\begin{array}{c}1966 / \\
67\end{array}$ & $\begin{array}{c}1963 / \\
64\end{array}$ & $\begin{array}{c}1966 / \\
67\end{array}$ & $\begin{array}{c}1963 / \\
64\end{array}$ & $\begin{array}{c}1966 / \\
67\end{array}$ & $\begin{array}{c}1963 / \\
64\end{array}$ & $\begin{array}{c}1966 / \\
67\end{array}$ & $\begin{array}{c}1963 / \\
64\end{array}$ & $\begin{array}{c}1966 / \\
67\end{array}$ & $\begin{array}{c}1963 / \\
64\end{array}$ & $\begin{array}{c}1966 / \\
67\end{array}$ & $\begin{array}{c}1963 / \\
64\end{array}$ & $\begin{array}{c}1966 / \\
67\end{array}$ \\
\hline Algeria & 81 & 48 & 61 & 33 & 76 & 57 & 12 & 10 & 6 & 56 & 9 & 2 & 73 & 73 & 318 & 279 & 25 & 24 \\
\hline Morocco & 3 & 10 & 16 & 26 & 27 & 63 & 0 & 8 & 10 & 35 & 0 & 0 & 95 & 107 & 151 & 249 & 28 & 30 \\
\hline Tunisia & 8 & 26 & 18 & 31 & 3 & 11 & 1 & 6 & 0 & 124 & 4 & 5 & 22 & 49 & 56 & 252 & 12 & 15 \\
\hline Sudan & 89 & 147 & 82 & 147 & 73 & 109 & 27 & 46 & 0 & 135 & 8 & 27 & 187 & 330 & 466 & 941 & 175 & 188 \\
\hline Egypt & 0 & 0 & 32 & 31 & 26 & 73 & 19 & 56 & 5 & 24 & 0 & 2 & 233 & 409 & 305 & 595 & 3 & 2 \\
\hline Syria & 247 & 461 & 165 & 230 & 144 & 195 & 26 & 51 & 60 & 177 & 15 & 38 & 207 & 473 & 864 & 1,625 & 65 & 319 \\
\hline Lebanon & 13 & 26 & 43 & 42 & 18 & 37 & 2 & 9 & 1 & 9 & 2 & 3 & 98 & 214 & 177 & 340 & 5 & 19 \\
\hline Jordan & 19 & 13 & 43 & 35 & 73 & 60 & 9 & 11 & 14 & 18 & 5 & 7 & 39 & 98 & 202 & 242 & 184 & 672 \\
\hline Iraq & 153 & 111 & 286 & 287 & 186 & 182 & 39 & 26 & 83 & 92 & 37 & 18 & 1,260 & 910 & 2,044 & 1,626 & 22 & 114 \\
\hline Yemen & 5 & 19 & 49 & 62 & 40 & 55 & 20 & 56 & 0 & 0 & 4 & 32 & 113 & 284 & 231 & 508 & 8 & 29 \\
\hline Other & 2 & 2 & 1 & 1 & 6 & 8 & 1 & 8 & 2 & 33 & 0 & 1 & 14 & 51 & 26 & 104 & 35 & 63 \\
\hline TOTAL & 620 & 863 & 796 & 925 & 672 & 850 & 156 & 287 & 181 & 703 & 84 & 135 & 2,341 & 2,998 & 4,840 & 6,761 & 562 & 1,475 \\
\hline
\end{tabular}

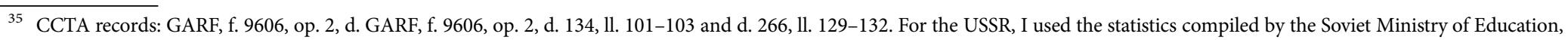
see GARF, f. 9606, op. 1, d. 1638, 11. 9-12 and d. 2699, 11. 1-5. For Yugoslavia, I draw from UNESCO, Statistics of Students Abroad, 1962-1968 (Paris: UNESCO, 1971). 
of large numbers of students in the East possible and, therefore, cooperation with the socialist countries even more attractive. Cost-benefit analyses, along with the conviction that studies at mainstream universities in most socialist countries were of a high level, thus prevailed over the fear of Marxist-Leninist indoctrination. When the perception that these conditions were not met became salient, cooperation was opposed. This was the stance of conservative Arab regimes, Egypt vis-à-vis Bulgaria and Romania and almost all Arab governments towards Patrice Lumumba University, whose scholarships they did not accept, and whose degrees very often they refused to accredit. These reservations notwithstanding, as evidenced by their eagerness to make careful deals and invest money, most Arab governments saw in the educational aid of the Eastern Bloc a great opportunity to increase and diversify their international cooperation. When in 1960 the United States refused to grant Tunisia a loan for the creation of the National School of Engineering of Tunis (the future École nationale d'ingénieurs de Tunis), even this Western-oriented country was able to reach out to the rival camp and secure a deal with Moscow. ${ }^{36}$

The creation of technical schools and the training of an elite that would run state enterprises, services and national energy industries were the primary motives on the Arab side. The socialist countries, on the other side, assessed the prospects for partnership enthusiastically and responded by eagerly granting aid and proposing their services. Not only did they have grants and affordable prices to offer, but education was also a field in which they could challenge the West, claiming their authority in planning, literacy campaigns, affirmative action policies, technical education and the systematic practical training of students. A combination of their perceptions, assessments and interests convinced them to make education a major tool in the political economy of their relations with the South.

\section{The Council for Mutual Economic Assistance and International Education}

The centrality of education in the international relations of the Eastern Bloc was reflected not only in the individual strategies of each country but also at the level of the Council for Mutual Economic Assistance (CMEA). In 1961 CMEA created the Permanent Commission for the Coordination of Technical Assistance (CCTA), within which CMEA members debated and sought to coordinate their development assistance and trade relations with the Third World. Along with economic relations, educational aid fell within CCTA's competence. Education was actually deemed to play a major role in the expansion of East-South ties. 'We consider that educational aid and the training of national elites is one of the most important and effective forms of our cooperation with the developing countries', stated a 'secret' CCTA report. ${ }^{37}$ Another stipulated that 'the provision of assistance of proper quality and in proper quantity to less developed countries to train specialists in our institutions of higher and secondary specialised education is a collective task of CMEA members', adding, however, that 'each CMEA member assumes its share of responsibility according to its capacity and conditions' ${ }^{38}$ To coordinate efforts it was agreed that 'the deputy ministers of education of CMEA countries, in charge of international cooperation, [would] form a working organ within the Commission'. ${ }^{39}$

Indeed, beginning in 1962 the deputy ministers held annual meetings to exchange views and information regarding the educational cooperation they pursued abroad and the training of students from developing countries at home. Their agendas included such subjects as recruitment policies, preparatory faculties, specialisations, study programmes and political education, both in formal classes and

36 Éric Gobe and Saïd Ben Sedrine, Les ingénieurs tunisiens : dynamiques récentes d'un groupe professionnel (Paris: L'Harmattan, 2004), 27.

37 Report from a CCTA meeting held in Budapest, in 14-17 Mar. 1967: GARF, f. 9606, op. 2, d. 266, 1. 36.

38 Report of 1963 cited in L. N. Kononenko, 'Deiatel'nost' partiinykh organizatsii vuzov Moskvy po internatsional'nomu vospitaniiu inostrannykh studentov' (The activity of party organisations at the institutions of higher education of Moscow with regards to the internationalist education of the foreign students), $\mathrm{PhD}$ Thesis for in-house use, Moscow Energy Institute, 1967, 3.

39 'Information on the work carried out in the meeting of deputy ministers of higher and specialized secondary education of CMEA member states', 26 Nov. 1966, 'secret': GARF, f. 9606, op. 2, d. 216, 1. 21. 
through extracurricular activities. ${ }^{40}$ At the second meeting that took place in Sofia in April 1963, it was decided that each member state would report to the CCTA on the schools it was constructing and equipping abroad and, if needed, ask other CMEA members to dispatch professors with sufficient knowledge of French or English. ${ }^{41}$ Following the 'Meeting of experts from CMEA member states on issues of political and ideological education of students from developing countries' held in the rebellious Prague in March 1968, a decision was simultaneously implemented in the Soviet Union, Czechoslovakia and East Germany that the courses of Marxism-Leninism, which until then were optional, would become compulsory for all Third World students. ${ }^{42}$ This decision provoked various reactions. In a characteristic vein, the Iranian embassy in Moscow voiced embarrassment that eleven Iranians, who studied industrial fishing in Leningrad and Astrakhan, would have to attend classes on Marxist-Leninist philosophy and political economy, thereby requesting their exemption. ${ }^{43}$ This and other reactions went unheeded.

Simultaneously, the CCTA gathered data, circulated long memorandums on the state of education in the Third World and issued recommendations stressing how important it was for all CMEA members to engage in educational exchange with the developing countries, supporting particularly the countries of socialist orientation. In 1973 the CCTA created a scholarship fund for the multilateral financing of students from developing countries, with the Soviet Union serving as the main donor and Algeria as the primary beneficiary. This fund remained operational until the late $1980 \mathrm{~s}^{44}$

To be sure, as evidenced by the mobility of Algerian students and the creation of the University of the 17th of November in Prague following the example of Patrice Lumumba University in Moscow, cooperation, the circulation of models and the emulation of policies within the Eastern Bloc had started before the CCTA was even created. The CCTA, however, did still become the institutional framework for inter-bloc cooperation and coordination in ways that have yet to be fully investigated and assessed. At the same time, it is safe to argue that beyond the commission's guidelines, each CMEA state increasingly pursued its own policy. Czechoslovakia, for example, decided to close the University of the 17th of November in 1974 after the disappointing results of a cost-benefit analysis. ${ }^{45}$ Hungary followed its own path in the commercialisation of international education. In the mid-1970s the Technical University of Budapest proposed study programmes both in the Hungarian language for recipients of Hungarian state scholarships who also attended preparatory facilities and in the English language for students whose families or states were eager to finance their studies and pay in hard currency, such as the Libyans. ${ }^{46}$ Romania, which until the mid-1970s had fully subsidised small numbers of students from developing countries, also jumped on the bandwagon and increasingly used international education for earning hard currency. ${ }^{47}$

40 Report of the 1967 meeting in Budapest: GARF, f. 9606, op. 2, d. 266, 1. 36-8.

41 See GARF, f. 9606 , op. 2, d. 266, 1. 140.

42 On this meeting, see the report of 31 July 1968 established by the Ministry of Higher and Specialized Education (Ministerium für Hoch- und Fachschulenwesen) of East Germany in: Bundesarchiv Berlin-Lichterfelde (hereafter BArch), DE 1/53799, p. 3.

43 Report of the Soviet Ministry of Foreign Affairs on the discussion with the first secretary of the Embassy of Iran, 26 Feb. 1971. His request applied also to another Iranian studying Russian language and literature. See GARF, f. 9606, op. 1, d. 4760 , 1l. $170-1$.

44 Mentioned in the 'Guidelines' the East German delegation at the CCTA meeting held in Tbilisi in Nov. 1975 received from the Central Committee of the Socialist Unity Party of Germany (Sozialistische Einheitspartei Deutschlands, SED), on 30 Oct. 1975. See 'Direktiven zur Vorbereitigung von Tagungen der Ständigen Kommission des RGW [Rat für Gegenseitige Wirtschaftshilfe] für die Koordinierung der Technischen Unterstützung', in BArch, DY 30/17734. Also mentioned by Heinrich Machowski and Siegfried Schultz, 'Soviet Economic Policy in the Third World', in Roger Kanet, ed., The Soviet Union, Eastern Europe and the Third World (Cambridge: Cambridge University Press, 1987), 127.

45 Holečková, 'Konfliktní'.

46 Fafali Koudawo, La Formation des Cadres Africains en Europe de l'Est depuis 1918. Des Nègres Rouges aux Russotiques (Paris: L'Harmattan, 1992), 131-2.

47 Mihai Dinu Gheorghiu et al., 'Les étudiants africains en Roumanie (1970-1990). De l'internationalisme militant à la commercialisation des études', Revista Psyhologia Socială, 34, 2, (2014), 117-28. 


\section{A Detour through Minorities, Confessional Communities and Stateless Actors}

Actors other than governments interested in training and staying on good terms with the elites and fostering economic relations, as well as other than leftist activists and CPs, seized the opportunity of the burgeoning educational cooperation to pursue their own objectives. This was particularly the case for members of the Armenian community in Lebanon and the Soviet Republic of Armenia within the Soviet Union. In keeping with Moscow's policy to mend fences with the Middle East, Soviet Armenia was quick to reach out to the Armenian diaspora in the region. The Soviet embassy in Beirut provided hundreds of scholarships to Lebanese Armenians who wished to receive higher education and see the homeland of the Armenian nation. Most of them studied Armenian in Erevan, where the union of Lebanese students was, in reality, a union of Lebanese Armenians. 'All the 98 students from the Middle East' who had enrolled in the Karl Marx Technical Institute of Erevan during the 1969-70 school term, for instance, 'were of Armenian nationality [sic]'. ${ }^{48}$ Recruited on national and not ideological criteria, some students were reportedly anti-communists, and many of them preferred to attend the Armenian national commemorations rather than the political meetings of the Communist Youth League (Komsomol). The illicit trade of books, disks and other items between Armenia and Lebanon flourished, leading to the trial and sentencing of Soviet citizens. ${ }^{49}$

The provision of scholarships to Lebanese Armenians was one specific case in which the national criterion prevailed over the mainstream political-ideological one in the recruitment of students. This move illustrates how Marxism, anti-imperialism and perhaps also economic interests were not the sole drivers of the Soviet Union's international education policy. It also suggests that different actors within the Soviet Union, either in Moscow or Erevan, came up with different goals and approaches which nevertheless were still committed to serving the same overarching goal of promoting useful ties with this region and furthering the interests of the Soviet Union. Thus, the Armenian connection was neither accidental nor irrelevant. Rather, it constituted an integral part of Soviet international cultural policies, whose repertoire was very broad and could not be reduced to the core political-ideological dimension.

More evidence suggests that officials and faculty members took into consideration the national and confessional geography of the Middle East in various ways. The Soviet ambassador in Teheran, for instance, would recommend the admission of an applicant to Lumumba University, stressing that he was both a progressive person and an ethnic Azeri. ${ }^{50}$ Lebanese Druze were recruited through the Progressive Socialist Party of Kamal Jumblatt, himself the recipient of the Lenin Medal for Peace in 1972, and whose portrait overlooked the hall of Lumumba University after he was assassinated in $1977 .^{51}$ Across the Eastern Bloc, stateless national groups like the Kurds were allowed to form their own unions and defend their national causes. The same was true for Palestinians, all of whom were recruited through nationalist and leftist organisations even before Moscow recognised the Palestine Liberation Organisation as the sole legitimate representative of the Palestinian people in $1978 .^{52}$

\section{The Creation of Schools in North Africa and the Middle East}

Czechoslovakia was not just the provider of arms to Middle Eastern countries, as has often been depicted. According to the files of the CCTA, during the early 1960s Prague was also an important actor in technical education across the region. In 1965 Czechoslovak companies were tasked to jointly construct the Technical Institute of Helwan with Egyptian partners and to provide it with

\footnotetext{
48 Report by the Institute's dean. See Russian State Archive of Social and Political History (RGASPI), f. M-1, op. 39, d. 286, 1. 1 .

49 RGASPI, f. M-1, op. 46, d. 310, 11. 30-6.

50 Ambassador G. Zaitsev to the vice-rector P. Erzin, 6 Apr. 1964: TsMAM, f. 3061, op. 1, d. 1404, 1. 28-31.

51 Koudawo, La Formation, 58. And Farid al-Khazem, 'Kamal Jumblatt, the Uncrowned Druze Prince of the Left', Middle Eastern Studies, 24, 2 (1988), 178-205.

52 Tareq Ismael, The Communist Movement in the Arab World (London: Routledge, 2005), 77.
} 
equipment. ${ }^{53}$ It was around the same time that the Soviet Union established the Helwan Steel Complex, one of the most successful ventures in the history of Soviet-Egyptian economic cooperation. A second nearby industrial complex, comprised of steel works, a coke and by-product unit, a foundry, a machine tool factory and other plants, was also established with the assistance of Czechoslovakia, East Germany, Romania and the Soviet Union. While the Technical Institute of Helwan was a vocational school that trained mechanics for these plants, the El-Tabbin Metallurgical Institute, established by the Soviet Union in 1971, trained managers and technical staff for higher level functions while also engaged in research activities. ${ }^{54}$

Between 1965 and 1968 Czechoslovak enterprises designed and provided construction material and equipment to two more professional-technical schools. The first was the Technical School of Tabriz, which, in the plans of Iranian officials, was to train workers and mechanics for the nearby tractor plant that Romania was about to establish. The second was the Training Centre for the National Railways of Iraq in Baghdad. ${ }^{55}$ During the same years, as mentioned earlier, the Soviet Union created the Institute of Engineering of Tunis, which in the 1970s became the National School of Engineering mainly through French assistance. ${ }^{56}$

By far the biggest educational project the Soviet Union pursued throughout the developing world during the Cold War was the establishment of the Algerian Oil and Gas Institute as part of the African Centre of Hydrocarbons and Textiles in Boumerdès. The centre also housed the Technical School of Textiles, yet the Oil and Gas Institute was clearly the most important institution in the developmental visions of Algerian policy makers. Financed by the Soviet Union as a gift of the Soviet people that Nikita Khrushchev offered to Ahmed Ben Bella in 1964, the entire educational complex employed around 200 Soviet professors and other staff, and had an enrolment capacity of one thousand students per year. The mission of the Oil and Gas Institute was to train manpower for the needs of the energy industry that the FLN government sought to place under the control of the state company Sonatrach. Indeed, in the late 1960s Algeria took over all oil fields from French and American companies, and in February 1971 the country did the same for the gas fields, raising Sonatrach into a state energy giant.

In this development, the educational assistance of the Soviet Union was instrumental. Algerian President Houari Boumediene publicly stressed the connection between Soviet educational assistance and the nationalisation of the hydrocarbon industry in May 1971 when he affirmed that, 'the recent cohorts of graduates of the African Centre of Hydrocarbons and Textiles had a major contribution [in this development] by replacing the foreign technicians and managers when our country got back her national oil riches'. ${ }^{57}$ What Boumediene, unlike other Algerian actors, failed to stress was the role played by another school, the Institut algérien du pétrole (IAP). Founded with French assistance, IAP would later also benefit from American and West German aid. ${ }^{58}$ Pitting donors against one another also in the field of education, Algeria succeeded in developing the necessary capacity to achieve a primary national goal.

East Germany was also invited to assist Egypt in developing her educational system shortly after the two countries established diplomatic relations. In June 1970 Cairo and East Berlin signed an agreement providing for the joint construction and development of the Technical School of Galal Fahmy in Shubra on the outskirts of Cairo. ${ }^{59}$ The school's mission was to 'train technicians and the qualified manpower that would be able to supervise the work of skilled workers and guide them through the production process so as to meet the necessary conditions for the industrialisation'

\footnotetext{
53 CCTA-CMEA report, 4 Apr. 1967: GARF, f. R-9606, op. 2, d. 266, 1. 45.

54 Raju Thadikkaran, Transfer of Soviet Technology to Steel Industry in Select Developing Countries, PhD Thesis, Jawaharlal Nahru University, 1991, 240-6.

55 CCTA-CMEA report, 4 Apr. 1967: GARF, f. R-9606, op. 2, d. 266, 11. 45-7.

56 Gobe and Sendrine, Les ingénieurs tunisiens, 27-9.

57 Hocine Khelfaoui, 'La formation des ingénieurs en Algérie : Le cas des Instituts Technologiques de Boumerdès', PhD Thesis, Université de Versailles, Saint-Quentin-en-Yvelines, 1997, 129.

58 Khelfaoui, 'La formation'; Moore, Combat, 334-5.

59 For the part that is related to the cooperation between Egypt and East Germany, I draw from Regnauld, 'La RDA'.
} 
of Egypt. Conceived as a means of reproducing the German model of polytechnic education in Egypt, the school offered courses in mathematics, physics, chemistry, technical design and the German language. The five-year study programmes were established by a joint team of experts. Egyptian lecturers, who had been trained in East Germany, taught alongside their German colleagues. Already in 1971 the school had enrolled the first 300 students, and by 1974, the number of students had reached 1,200.

In March 1972, after the Galal Fahmy Technical School had become fully operational and was considered by both sides to be a very successful undertaking, Egypt and East Germany signed a new agreement, this time for the construction of the experimental school of Medinet Nasr. This school was an institution of both primary and secondary level education, catering to students from six to fourteen years of age and offering general education study programmes along the lines of a general education school (Allgemeinbildende Schule). In the beginning classes on mathematics, natural sciences and the German language were taught by German teachers. Their Egyptian colleagues, who attended training programmes in pedagogy in East Germany, joined the school later. Medinet Nasr was also considered by both sides to be a success story. As a result, in 1976 the Egyptian Ministry of Education asked East Germany to extend the study programmes so as to train students up to the age of seventeen. The aim was for Medinet Nasr to evolve into a technical secondary school along the lines of Galal Fahmy. In the same year, the Egyptian Minister of Education Ahmed Talaat Osman submitted a request for aid to East Germany in order to create three new technical institutes modelled on Galal Fahmy. These projects, however, never materialised. As the sources indicate, it was the German side that was no longer eager to provide assistance for such projects, specifically by refusing to cover a large part of the costs for the teaching staff. Therefore, it is economic considerations, and neither educational nor political matters, that appear to lie behind East Berlin's retreat from educational cooperation with Egypt. ${ }^{60}$

However, oil-rich Algeria was eager to invest in Soviet educational cooperation. In the 1970s the Soviet Union developed the Technical School of Textiles, which became the National Institute of Light Industry, and established the Institute of Mining and Smelting in Annaba. Like the El-Tabbin Institute in Egypt, the one in Annaba trained manpower for the nearby El Hadjar Iron and Steel Complex, part of which was also developed with Soviet aid. As a result, in 1980, Algeria employed 953 Soviet expatriates in its higher and professional-technical education system, constituting their second destination abroad after East Germany (which hosted 1,287 Soviet professors). In El-Tabbin, the number of Soviets dropped from sixty-six in 1975 to thirty-five in 1980. In Tunisia, however, which during the same period was the third most popular destination for Soviet professors throughout North Africa and the Middle East, their number rose from sixty-one in 1975 to seventy in 1980, and then to eighty in 1984. In Syria during the early 1980s there were around ten Soviet experts assisting in the development of an automotive training school in Damascus and establishing technical centres within the Polytechnic Institute of Homs. ${ }^{61}$

\section{The Training of Students in the Eastern Bloc: Objectives, Policies and Trends}

Given that several educational institutions established in North Africa and the Middle East with Eastern Bloc assistance trained manpower for employment in industries or other projects also developed with Eastern Bloc assistance, the training of students in the socialist countries often conformed to a similar logic or simply served the objectives of the sending countries that were not directly related to Eastern Bloc technical cooperation. Egyptian engineers educated in the Soviet Union worked in the Aswan Dam along with Soviet experts. ${ }^{62}$ 'Fifteen graduates of the Faculty of Physics of Moscow State University', according to another source, 'pursued research under the supervision of Soviet

60 Regnauld, 'La RDA', 353-6.

61 According to the Annual Reports of the Soviet Ministry of Education for the years 1975, 1980 and 1984: GARF, f. 9606, op.1, d. 6829, 1l. 40-1, d.9120, 11. 85-8, and op. 3, d. 606, 11. 69-85. See also Pedro Ramet, The Soviet-Syrian Relationship since 1955: A Troubled Alliance (Boulder: Westview Press, 1990), 223.

62 Kononenko, 'Deiatel'nost', 221. 
professors at the Centre for Nuclear Energy in Egypt', which the Soviet Union had also helped to set up. ${ }^{63}$ The 1973 Agreement between the Academies of Science of Egypt and East Germany provided funding for the training of researchers in fields crucial for Egypt's development, from biochemistry to the cultivation of cereals and the production of textiles. ${ }^{64}$ In the mid-1970s Tunisian graduates of ENIT and Algerian graduates of the Oil and Gas Institute were pursuing further training in the Soviet Union. ${ }^{65}$ Ten years later Algeria and the Soviet Union discussed the interlinked issues of education and development in the meetings of the Permanent Inter-governmental Commission for Economic and Scientific-Technical Cooperation. ${ }^{66}$ Other Algerian students who had made it to the top of the country's oil and chemical industry attended schools in Hungary and Romania. ${ }^{67}$

Apart from energy and civil engineering, other specialisations of great importance for the sending countries also figured prominently in the Eastern Bloc-Middle East educational cooperation. Training specialists for civil aviation, for example, was necessary for countries like Syria and Iraq that relied heavily on Eastern Bloc assistance, but it was equally interesting to CMEA members who coveted this market and aimed to establish their presence in airspace. Czechoslovakia provided training and technical aid for this purpose in the early 1960s. By the mid-1970s, the school that had trained the largest number of Third World students was the prestigious Institute of Civil Aviation Engineering in Kiev. ${ }^{68}$ According to aggregate data covering all CMEA members that the CCTA compiled in 1963, 40.6 per cent of students from North Africa and the Middle East pursued their studies in the fields of engineering, transport, industry and communication technologies; 25.4 per cent in medicine and medical specialisations; 21.7 per cent studied economy or law and 6.2 per cent were in agronomy. The remaining 6.1 per cent had studied humanities and the arts, including such disciplines as archaeology, literature, theatre and cinema. ${ }^{69}$

Arts education and cinema in particular, however marginal they might have been in terms of the percentage of the training programmes or with respect to their contribution to economic development, nonetheless constituted one of the most important fields of cooperation. Not only VGIK, FAMU and the Berlin School but also the Kiev Institute of Cinematography in Ukraine and the Lodz School in Poland opened their doors to students who often dropped out of other faculties to become the pioneers of national cinema in their respective countries. ${ }^{70}$ Soviet masters of cinema and the aesthetics of socialist realism became a source of inspiration for influential filmmakers such as the Algerian Lakhdar-Hamina or the VGIK-educated and award-wining Syrian Ossama Mohammed. Conscious of the extraordinary possibilities that cinema, television and the arts offered to reach out to domestic and international audiences, Arab governments supported the training of students in these fields. As a consequence, most students of cinema and the plastic arts were holders of state scholarships. ${ }^{71}$

${ }_{63}$ Komsomol report of 1966, see RGASPI, f. M-1, op. 39, d. 136, 1. 45.

64 Regnauld, 'La RDA', 341.

65 For this cooperation between ENIT, the Oil and Gas Institute and Soviet schools, see the 1975 report of the Soviet Ministry of Education: GARF, f. 9606, op. 1, d. 6829, 1l. 35-8.

66 See the 1984 Report of the Soviet Ministry of Education: GARF, f. 9606, op. 3, d. 606, 1. 16.

67 I draw from the account of Choaieb Taleb, Algerian diplomat and author, who also refers to Abdelmajid Kazi-Tani, the Romanian-trained director of SN REPAL (Société nationale de recherche et d'exploitation de pétrole en Algérie). See Moore, Combat, 414.

68 For Czechoslovakia, see Philip Muehlenbeck, Czechoslovakia in Africa, 1945-1968 (Basingstoke: Palgrave Macmillan, 2016), 125-56, who also refers to Morocco and Sudan. For the Kiev Institute of Civil Aviation Engineering, see the Institute's 1974 report which enlists many graduates who held important positions: Central State Archives of Supreme Bodies of Power and Government of Ukraine (TsDAVO), f. 4621, op. 13, d. 2991, 11. 13-4.

69 Unfortunately, the category 'medicine and medical specialisations' also includes students in physical education, which, however, according to all evidence, made up a very small percentage. See GARF, f. 9606, op. 2, d. 143, 11. 105-7.

70 This was the case of Abdellah Ouahhabi, Un Beur à Moscou (Paris: Éditions Robert Laffont, 1988). I also draw from Léa Morin and Marie Pierre-Bouthier, 'Studying Abroad to Become a Moroccan Filmmaker: A (Trans)national Imaginary Cinema? The cases of Mustapha Derkaoui and Abdelkader Lagtaâ in Lodz', paper presented at the conference, 'Morocco in Motion: The Global Reach of Moroccan Cinema', University of Edinburgh, 26-28 Oct., 2018.

71 Chomentowski, 'Filmmakers'; Anahi Alviso-Marino, 'Impact of Transnational Experiences', Arabian Humanities: International Journal of Archaeology and Social Sciences in the Arabian Peninsula, 1, (2013), 1-26. http://cy.revues.org/ 2229 (last visited 30 June 2021). 
If the training of students in Europe and across the Soviet Union entailed a significant cost from the standpoint of individual host socialist countries and the CCTA, it also appeared to have important advantages compared to the creation of schools abroad. Such training provided plenty of opportunities to teach the students Marxist-Leninist philosophy and political economy, and to familiarise them with the history of the Soviet Union and international communism. Making the students good friends of the socialist camp was another major objective of the aid, and there is plenty of evidence that this aim was reached. Beyond the long-term economic considerations, some officials also assumed that, in the future, students would become customers of Eastern Bloc-made products. ${ }^{72}$ Last but not least, selected international students, usually coming 'from rich and influential families', were approached by secret services like the KGB to serve as agents abroad. ${ }^{73}$ In any case, along with the varying motives of foreign students, governments, parties and organisations, all these objectives had major effects in terms of sponsoring students' training. These effects are to some extent captured by the following tables.

Student migration from North Africa and the Middle East to the socialist countries witnessed spectacular growth during the 1960s. Data from the CCTA records that CMEA member countries did not share with international organisations reflect this development. ${ }^{74}$ From Iraq to Jordan to Morocco, states which until then had very few (if any) cultural relations with the Soviet Union and Eastern Europe were all of a sudden seeing increasing numbers among their best educated young people pursuing post-secondary education in a socialist country. That these student flows and educational relationships connected a region that was hitherto a theatre of Western European imperialism and interventions to the socialist world lends them even greater significance. So, too, does a comparison with data on student migration to Western Europe that are accessible in UNESCO's statistical yearbooks. Despite the gaps as well as the differences in the measurements and the nature of student migrations, the broader picture that appears in Table 2 is revealing. For every three students from the Arab world studying in Western Europe in 1964, there was one student in the Eastern Bloc and Yugoslavia. In 1967 the rate was two to one. With all caveats in mind, this trend translated into a new reality in the region's cultural relations with Eastern and Western Europe.

After the 1960s this dynamic was not exhausted. According to the data available and compiled in Table 3, the Soviet Union was the third most important destination for students from the Arab world after France and the United States. In France, however, the overwhelming majority of students came from the former French empire, and many of them had planned not only to study but also to stay permanently in the country. In the United States and the Soviet Union, the picture was different and more diversified, even though both superpowers also had privileged relationships: the United States with Saudi Arabia on the one hand and the Soviet Union with Syria on the other. Lebanon sent students to all three major host countries. It is important to remember, however, that all Lebanese students in the Soviet Union studied on scholarships provided by Soviet organisations, an arrangement that was not at all the case in the United States, where Lebanese and other international students usually paid fees. Likewise, all students from North and South Yemen who pursued education in the Eastern Bloc did so on Eastern Bloc scholarships. As political scientist Fred Halliday has shown, the Marxist ally South Yemen became a major multilateral development project of the Eastern Bloc during the Cold War. ${ }^{75}$ The training of thousands of Yemenis constituted an integral part of this project.

East Germany's contribution to training students was equally important and overall, mutatis mutandis, as important as the West German one. As Table 4 illustrates, for approximately every four students from the Arab world studying in West Germany during the 1960s and 1970s, there was one student in East Germany. During the 1980s, this rate increased to nearly two to one. It should

72 Uladh, 'Guests', 43.

73 See the secret KGB report of 23 Sept. 1970 in the State Archive of the Security Service of Ukraine (SBU), f. 16, op. 13, d. $1000,1.223$.

74 CMEA member countries used to communicate to the UNESCO scattered, underestimated and aggregate per continent numbers of international students.

75 Halliday, Revolution, 197-223. 
Table 2. Students from the Arab countries in Eastern Europe/Soviet Union and Western Europe in 1964 and $1967 .^{76}$

\begin{tabular}{|c|c|c|c|c|}
\hline \multirow{2}{*}{$\begin{array}{l}\text { Year } \\
\text { Regions / Individual Countries }\end{array}$} & \multicolumn{2}{|c|}{1964} & \multicolumn{2}{|c|}{1967} \\
\hline & Number & $\%$ & number & $\%$ \\
\hline CMEA and Yugoslavia & 5,402 & $26 \%$ & 8,236 & $33,6 \%$ \\
\hline Western Europe & 15,431 & $74 \%$ & 16,279 & $66,4 \%$ \\
\hline France & 6,388 & $30,7 \%$ & 6,677 & $27,2 \%$ \\
\hline United Kingdom & 1,710 & $8,2 \%$ & 1,513 & $6,2 \%$ \\
\hline West Germany & 3,672 & $17,6 \%$ & 3,135 & $12,8 \%$ \\
\hline East Germany & 672 & $3,2 \%$ & 850 & $3,5 \%$ \\
\hline Soviet Union & 2,341 & $11,2 \%$ & 2,998 & $12,2 \%$ \\
\hline TOTAL - Students from Arab countries in Europe & 20,833 & $100 \%$ & 24,515 & $100 \%$ \\
\hline
\end{tabular}

Table 3. Students from the Arab countries in France, the United States and the Soviet Union in selected years. ${ }^{77}$

\begin{tabular}{|c|c|c|c|c|c|c|c|c|c|c|}
\hline & \multicolumn{3}{|c|}{ France } & \multicolumn{3}{|c|}{ United States } & \multicolumn{4}{|c|}{ Soviet Union } \\
\hline & Maghreb & Lebanon & $\begin{array}{c}\text { Arab } \\
\text { countries } \\
\text { TOTAL }\end{array}$ & $\begin{array}{l}\text { Saudi } \\
\text { Arabia }\end{array}$ & Lebanon & $\begin{array}{c}\text { Arab } \\
\text { countries } \\
\text { TOTAL }\end{array}$ & Syria & Lebanon & $\begin{array}{l}\text { Yemen } \\
\text { (North \& } \\
\text { South) }\end{array}$ & $\begin{array}{c}\text { Arab } \\
\text { countries } \\
\text { TOTAL }\end{array}$ \\
\hline 1962 & 4,775 & 619 & 6,038 & 271 & 602 & 4,274 & 54 & 95 & 109 & 2,273 \\
\hline 1966 & 4,962 & 882 & 6,572 & 807 & 773 & 5,389 & 393 & 181 & 232 & 2,725 \\
\hline 1971 & 6,752 & 1,985 & 10,072 & 835 & 1,254 & 6,156 & 871 & 394 & 459 & 4,044 \\
\hline 1974 & 19,032 & 2,499 & 24,090 & 1,540 & 1,580 & 8,826 & 1,222 & 560 & 679 & 5,881 \\
\hline 1978 & 32,115 & 5,100 & 40,975 & 8,050 & 4,380 & 26,300 & 1,585 & 1,005 & 1,530 & 8,718 \\
\hline 1984 & 44,767 & 4,589 & 54,788 & 6,636 & 5,934 & 33,434 & 3,128 & 2,545 & 2,691 & 17,155 \\
\hline 1989 & 45,954 & 5,064 & 55,812 & 3,703 & 4,014 & 23,948 & 5,093 & 3,499 & 3,569 & 21,812 \\
\hline
\end{tabular}

Table 4. Students from Arab countries in East and West Germany in selected years. ${ }^{78}$

\begin{tabular}{lrr}
\hline & East Germany (in \%) & West Germany (in \%) \\
\hline 1967 & $850(21,3 \%)$ & $3,135(78,7 \%)$ \\
1974 & $992(23,6 \%)$ & $3,205(76,4 \%)$ \\
1980 & $1,111(23,2 \%)$ & $3,671(76,8 \%)$ \\
1983 & $1,540(28,8 \%)$ & $3,800(71,2 \%)$ \\
1985 & $2,228(36,1 \%)$ & $3,948(63,9 \%)$ \\
1988 & $2,071(31,6 \%)$ & $4,492(68,4 \%)$ \\
\hline
\end{tabular}

be borne in mind, however, that this evolution was partly due to the big cohorts of Syrians and Libyans who enrolled in East German schools on a commercial basis. In 1985, Syrians constituted the biggest group, boasting 822 students, followed by 451 Yemenis. $^{79}$

76 Ibid. For the Western countries, I also draw from UNESCO, Statistics.

77 For France and the US, I draw from UNESCO's Statistical Yearbooks. For the USSR, see GARF, f. 9606, op. 1, d. 869, d. 2699, d. 4387, d. 6485, d. 8151, op. 3, d. 608 (for 1984) and f. 9661, op. 1, d. 589 (for 1989).

78 Data for West Germany come from UNESCO's Statistical Yearbooks. Regarding the GDR, for the year 1967 they come from the CCTA records cited earlier; for 1974 see BArch, DE 2/23039, Bandnummer 65, 'Studierende Ausländer'; and for the years 1980, 1983, 1985, and 1988, see BArch, DR 3/24072.

79 Syrians constituted the biggest group not only from the Middle East but from all over the world, surpassing countries like the Soviet Union and Vietnam, which boasted 782 and 751 students respectively. 


\section{Conclusion}

This article has shown how educational cooperation with the socialist countries was both welcome and relevant in the development and state building endeavours of North African and Middle Eastern countries, while it also served their purpose to diversify their international relations. It has further maintained that education was instrumental in the international policies of the socialist countries and important in the political economy of their relations with North Africa and the Middle East. To substantiate these claims this article points not only to the views expressed by policy makers but, more importantly, also to the sponsoring of thousands of students along with the creation of schools serving specific purposes, such as the training of specialists for a particular industry in the process of nationalisation, or for industrial projects developed with Eastern Bloc assistance.

These strands of Eastern Bloc-Middle East relations are essentially absent in the Cold War-era scholarship focusing on leadership and military build-up. They were then dismissed after 1989-91, when it became clear that this kind of peaceful cooperation would not bring about detrimental effects in terms of socialist economic policies and alliances. Without subscribing to the triumphalist post-Cold War narrative, it is indeed safe to argue that many of the actors' expectations before 1989 were not fulfilled. Sadly, it cannot escape notice that the two countries in which this huge investment in training human resources was expected to bear fruit, namely Syria and Yemen, became theatres of apocalyptic wars that make any search for effects and legacies a complicated and painful exercise.

Nevertheless, such conclusions should neither diminish the historical significance of the EastSouth educational cooperation, nor distract attention from its concrete effects. Schools were created, doctors and engineers were trained and energy companies were nationalised. Students of cinema became prominent filmmakers, and several Marxist and socialist-minded economists, thinkers and writers attended universities in the Eastern Bloc. ${ }^{80}$ The Kurdish scholars who established Kurdology in Iraq were Soviet PhDs. ${ }^{81}$ Lebanese Armenians received higher education and connected the diaspora to Soviet Armenia. ${ }^{82}$ Chapters of this story fit within the scope of the global Cold War paradigm, while others, like those of the Kurdish and Lebanese Armenian students, probe the limits of this paradigm and invite a different historical approach. ${ }^{83}$ The easy way through this historical endeavour would be to dismiss these chapters altogether simply because state socialism failed. The difficult but edifying alternative is to retrieve them. New research will certainly unearth more missing chapters and links, thereby broadening our understanding and correcting our assessments.

Acknowledgements. Funding for this article was provided by the Bayreuth Academy of Advanced African Studies at Bayreuth University. I am grateful to the editors and the three anonymous reviewers for their astute remarks. My sincere gratitude also goes to Professor Birgit Schäbler, Dr. Ala al-Hamarneh and our colleagues in the project 'Relations in the Ideoscape: Middle Eastern Students in the Eastern Bloc, 1950-1991' at the Orient Institute in Beirut.

\footnotetext{
80 See for instance Margaret Litvin, 'Fellow Travelers? Two Arab Study Abroad Narratives of Moscow', in Roberta Micallef, ed., Illusions and Desillusionment: Travel Writing in the Modern Age (ILEX/Harvard University Press, 2018), 96-119.

81 Michiel Leezenberg, 'Soviet Kurdology and Kurdish Orientalism', in Michael Kemper and Stephan Kornemann, eds., The Heritage of Soviet Oriental Studies (London: Routledge, 2011), 95-6.

82 For the history of repatriations to Soviet Armenia, see Joanne Laycock, 'Armenian Homelands and Homecomings, 19459', Cultural and Social History, 9, 1 (2012), 103-23.

83 This approach may draw inspiration from Ludovic Tournès and Giles Scott-Smith, 'A World of Exchanges: Conceptualizing the History of International Scholarship Programs (Nineteenth to Twenty-First Centuries)', in their edited volume, Global Exchanges: Scholarships and Transnational Circulations in the Modern World (New York: Berghahn Books, 2017), 1-29.
}

Cite this article: Katsakioris C (2021). The Socialist Countries, North Africa and the Middle East in the Cold War: The Educational Connection. Contemporary European History 30, 597-612. https://doi.org/10.1017/S0960777321000345 